\title{
時系列情報処理のためのニューロンモデル
}

\author{
非会員山片茂 樹(日本電気) \\ 正員吉江修（東京理科大）
}

\begin{abstract}
A Neuron Model for Time Series Information Processing
Shigeki Yamagata, Non-member (NEC), Osamu Yoshie, Member (Science University of Tokyo)
\end{abstract}

キーワード：ニューラルネットワーク．時系列処理, 言号差逆伝搬学習則, フィルタリング

1.はじめに

時系列情報処理のためのニューラルネットワータと して層単位のフィードバックを有するリカレントネッ トが有名である。しかしながら，このモデルにはメモ リー量と計算量に問題があり，また最適化アルゴリズ ムには近似を用いている(1)。

そこで,ここではニューロンのシナプス結合強度に フィルタリング機能をもたせることにより，ニューロ ンそのものに時系列に対処する能力をもたせる方法を 提案する。この考え方自体は決して新しいものではな い(2)が, 著者らの目的は、フィルタリング機能をも つニューロンモデルを用いた Perceptron 型ネットワ ークに対し，出力層での受差の逆伝搬近似なしに行 えることを示すことである。

\section{2. フィルタリングニューロンの提案}

愦差逆伝搬 Perceptron 型のネットワークにおいて は, ニューロンの時間的加算の動作は無視されている ので,シナプス荷重を単なる定数ではなしに, 線形つ イルタとする。このことは, 前居のニューロンの出力 にフィルタのインパルス応答を畳込んでニューロンの 内部状態人の寄与分とすることを意味しており，フィ ルタのインパルス応答がある程度長いことが必要とな る。従って, FIR 型のフィル夕よりもIIR 型のフィ ルタで重み形成するほうが，ネットワータのパラぬ 一夕数の面で有利である。説明に際しては次の記号を 用いる。

$\theta_{j}^{k+1}:$ 第 $(k+1)$ 層 $j$ 細胞のしきい值

$W_{i, j}^{k, k+1}(z):$ 第 $k$ 層 $i$ 細胞間の重更フィルタ

$$
=\frac{b_{i, j, 0}^{k, h+1}+b_{i, j, 1}^{k, k+1} z^{-1}+\cdots+b_{i, j, m}^{k, k+1} z^{-m}}{1-a_{i, j, 1}^{k, k+1} z^{-1}-\cdots-a_{i, j, n}^{k, k+1} z^{-n}}
$$

$$
=\frac{B_{i, k+1}^{k, k+1}(z)}{A_{i, j}^{k, k+1}(z)}
$$

$R_{j}^{k+1}(z)$ :第 $(k+1)$ 層 $j$ 細胞の内部状態つィード バック係数

$$
=r_{j, 1}^{k+1}+r_{j, 2}^{k+1} z^{-1}+\cdots+r_{j, n}^{k+1} z^{-n+1}
$$

$x_{i}^{k}(t)$ : 時刻 $t$ での第 $k$ 層 $i$ 紏胞の内部状態 $O_{j}^{k+1}(t):$ 時刻 $t$ での第 $(k+1)$ 層 $j$ 細胞の出力 $y_{j}^{M}(t)$ : 出力層（第 $M$ 層）での教師信号

$E^{M}=(1 / 2) \sum_{i=1}^{n_{M}}\left\{y_{i}^{M}(t)-o_{i}^{M}(t)\right\}^{2}$

$\delta_{i}^{k}(t)=\partial E^{M} / \partial x_{i}^{k}(t), n_{k}$ : 第 $k$ 層の細胞数

$f(x)$ : 微分可能な入出力関数

シナプス荷重を定数でなくIIRフィルタのパルス伝 達関数 $W_{i_{j}}^{k, k+1}(z)$ としたモデルに対し，誤差逆伝搬标 よびパラメー夕更新式を最急降下法により厳密に導く ことはできるが, 䒠用面から重みつィルタのAR 部 をニューロンごとに共通とする。すなわち，第 $k$ 層 と第 $k+1$ 層の間の重みは,

$A_{i, j}^{k+1}(z)=1-z^{-1} R_{i}^{k+1}(z)$, for all $1 \leqq i \leqq n_{k}$ とする。

このとき，第 $k+1$ 潶 $j$ 細胞の時刻 $t$ における出力 計算式, 融差道伝搬式およびパラメータ更新式は次の ようになる。

$$
\begin{aligned}
& x_{j}^{k+1}(t)=\sum_{i=1}^{n_{n}} B_{i, j}^{k, k+1}(z) o_{i}^{k}(t) \\
& +R_{j}^{k+1}(z) x_{j}^{k+1}(t-1)-\theta_{j}^{k+1} \\
& o^{k+1}(t)=f\left\{x_{j}^{k+1}(t)\right\} \\
& \text { (愦差逆伝搬式) } k=(M-1) \sim 1 \text { ： } \\
& \delta_{i}^{k}(t)=f^{\prime}\left\{x_{i}^{k}(t)\right\} \sum_{j=1}^{n_{k+1}} \zeta_{i, j}^{k, k+1}(t) \\
& \zeta_{i, j}^{k, k+1}(t)=B_{i, j}^{k, k+1}(z) \delta_{j}^{k+1}(t)+R_{j}^{k+1}(z) \zeta_{i, j}^{k, k+1}(t-1)
\end{aligned}
$$




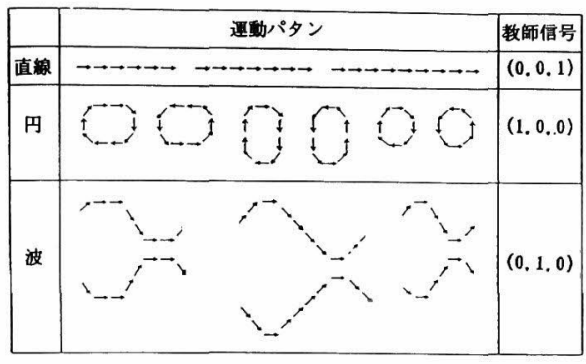

図 1 運動パターン

Fig. 1. Motion patterns.

$$
\begin{aligned}
& \text { 〔係数更新式〕 } k=(M-1) \sim 1 \text { : } \\
& \Delta r_{j, s}^{k+1}(t)=\eta_{1} \delta_{j}^{k+1}(t) x_{j}^{k+1}(t-s) \\
& +\alpha_{1} \Delta r_{j, s}^{k+1}(t-1) \quad(s=1 \sim n) \\
& \Delta b_{i, j, s}^{k, k+1}(t)=\eta_{2} \delta_{j}^{k+1}(t) O_{i}^{k}(t-s) \\
& +\alpha_{2} \Delta b_{i, j, s}^{k, k+1}(t-1) \quad(s=0 \sim m) \\
& \Delta \theta_{j}^{k+1}(t)=\eta_{2} \delta_{j}^{k+1}(t)+\alpha_{2} \Delta \theta_{j}^{k+1}(t-1)
\end{aligned}
$$

3. シミュレーション

簡単な運動パターンの認識を行ったので, それにつ いて述べる。運動パターンとしては図 1 に示した 15 種類を用意した。ニューラルネットワークへの入力 は, 1 時刻前のべクトルに対する相対的な向きの変化 分であり, 右回り $45^{\circ}$ だけ変化する場合には $(0,0,1)$, 角度変化なしの場合には $(0,1,0)$, 右回り $45^{\circ}$ のをき には $(1,0,0)$ とした。例えば， 6 ベクトルの「波」の 場合，ネットワークへの入力と教師信号は図 2 のよう になる。シミェレーションには 3 層のネットワークを 用い, ニューロン数は入力層が 3 , 中間層が 8 , 出力 層が 3 である。またシナプスのパルス伝達関数の次数 は, $\mathrm{AR}$ 部, $\mathrm{MA}$ 部ともに 1 次である。学習効率 $\eta_{1}$, $\eta_{2}$ は 0.05 とし, 慣性項係数 $\alpha_{1}, \alpha_{2}$ は 0.8 とした。

まず, 図 1 に示した 15 種類のパターンを学習させ たところ，3,000 回程度の繰返しで収束し，これら 15 種類のパターンは正しく認識できることがわかった。

また, 図 3 に示す 5 種類のパターンのみを学習さ せ，末学習パターンを含む図 1 の 15 パターンを入力 したところ，すべて正しく認識できることが確認され た。

\section{4.おわりに}

上記のシミャレーションとは別に, XORの識別実 験を行ったところ, 学習により過去値の重みが 0 に近 くなることにより, 問題なく識別可能との結果が得ら れた。以上は, 提案したモデルが従来のモデルを含む ことを示唆するものである。(平成 5 年 2 月 2 日受付)

\begin{tabular}{|c|c|c|c|c|}
\hline 時刻 & 人カベクトル & 時系列符号 & 入力信号 & 教師后号 \\
\hline$t-5$ & $t$ & 0 & $(0,1.0)$ & $(0.1 .0)$ \\
\hline$t-4$ & - & +1 & $(0.0 .1)$ & $(0.1 .0)$ \\
\hline$t-3$ & $v$ & +1 & $(0.0 .1)$ & $(0.1 .0)$ \\
\hline$t-2$ & $\checkmark$ & 0 & $(0,1.0)$ & $(0.1 .0)$ \\
\hline$t-1$ & - & -1 & $(1.0 .0)$ & $(0.1 .0)$ \\
\hline$t$ & - & -1 & $(1,0.0)$ & $(0,1.0)$ \\
\hline
\end{tabular}

図 2 入力データの例

Fig. 2. An example of input data.

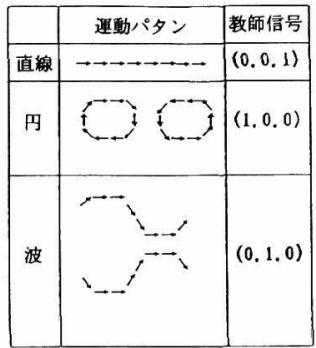

図 3 汎化能力検証のための運動パターン

Fig. 3. Motion patterns for examining the generalization ability of network.

\section{文献}

(1) Rumelhart, et al. . Parallel distributed processing (1986) The MIT Press

（2）甘利: 神経回路網の数理, 産業図書

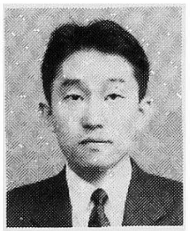

山片 茂 樹 (非会員)

昭和 60 年早稲田大学理工学研究科修 士課程修了。同年日本電気(株) 入社, 現 在に至る。レーザレーダ応用システムの 開発に従事。

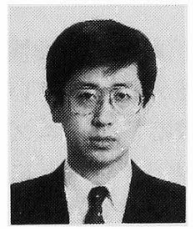

吉 江修（正員）

昭和 62 年早稲田大学理工学部研究科 博士課程修了。現在, 東京理科大学理学 部応用物理学科講師。再像理解などの研 究に従事。 